\title{
REVIEW
}

\section{David Berger}

\section{Persecution, Polemic, and Dialogue: Essays in Jewish-Christian Relations}

(Boston: Academic Studies Press, 2010), hardcover, xiv + 437 pp.

Reviewed by Daniel J. Lasker, Ben-Gurion University of the Negev and Boston College

Over the years, David Berger has earned for himself the well-deserved reputation as being one of the most thoughtful and insightful students of the medieval Jewish-Christian encounter. His works include the seminal The Jewish-Christian Debate in the High Middle Ages (1979), which incorporates an edition and annotated translation of Nizzahon Yashan, one of the most significant, and acerbic, medieval Jewish anti-Christian polemics (the introduction to which is reproduced in this book). Yet Berger is not solely an uninvolved scholar, and he has taken an active role in contemporary discussions between Jews and Christians (as well as co-authoring a short polemical treatise against "Jewish Christianity"). In general, Berger advocates a relationship which is respectful but does not require a blurring of theological commitments or reciprocal doctrinal concessions. An important spokesman for American Centrist Orthodoxy, Berger is now the dean of the Bernard Revel Graduate School of Jewish Studies at Yeshiva University, after a long career at Brooklyn College. This collection of previously published essays, 22 in number and the product of 45 years of scholarship, advocacy, and introspection, examines numerous historical and current aspects of the Jewish-Christian encounter.

Persecution, Polemic, and Dialogue is divided into two main parts. After a short introduction and an overview of anti-Semitism, the longer first part of the book ("The Middle Ages") is devoted mainly to "persecution" and "polemic," whereas the second part ("Modern and Contemporary Times") examines "dialogue" in its various forms. The articles in the first part include technical investigations of literary borrowings ("Gilbert Crispin, Alan of Lille, and Jacob ben Reuben: A Study in the Transmission of Medieval Polemic"), studies on one particular polemical author or text (Bernard of Clairvaux; Peter Damian; Moses ha-Kohen of Tordesillas's Ezer ha-Emunah), and broad overviews of specific topics (images and destiny of Gentiles in Ashkenazic literature; new approaches to the study of anti-Semitism; the uses of history in the medieval Jewish polemic). The second part starts with the views of Jesus and early Christianity held by the Jewish historian and biblical scholar Yehezkel Kaufman but quickly jumps to such present-day issues as perspectives on dialogue; Dabru Emet, a Jewish response to Christian attempts at rapprochement with Judaism; and Mel Gibson's The Passion. Demonstrating his erudition, Berger treats both the historical and contemporary studies with clarity of expression and sensitivity to the deeper issues involved.

In a short review it is impossible to discuss every article or even to give an adequate overview of the entire book, but I would like to write a few words about two essays, one from each part. Berger's discussion of twelfth-century Christian anti-Jewish polemical literature ("Mission to the Jews and Jewish-Christian Contacts in the Polemical Literature of the High Middle Ages") is a welcome corrective to the traditional historiography that the Jewish critique of Christianity is 
solely a response to the Christian mission. Even Berger himself is not immune to the traditional narrative as he writes in a different context: "Jews had no internal motivation for writing polemics against Christians; in times or places where Christianity is not a threat, we cannot expect Jews to be concerned with the refutation of its claims" (p. 79). Yet, in the past few decades, more and more evidence has become available that Jews did criticize Christian doctrines even when not threatened by Christian missionaries. Berger demonstrates that Christians wrote anti-Jewish polemics in the twelfth century as a response to a Jewish challenge, not as part of an active missionary campaign. The evidence that Berger accumulates to support his revisionist view is important for a rewriting of the history of the Jewish critique of Christianity.

Berger's negative response to Dabru Emet might be read merely as a reflection of the Orthodox reluctance to engage in theological dialogue with, or to make concessions to, Christianity. That would be too simplistic a reading, however. Berger's concern for historical accuracy, as well as theological integrity, compels him to analyze the weaknesses implicit in the Jewish statement concerning Christianity. He is troubled by an assumption that dialogue requires theological reciprocity and relativism, while often descending into demands that one side or the other be obligated to hold certain religious beliefs as a pre-condition for fruitful discussions. Berger takes Judaism, and Christianity, much too seriously to justify these almost inevitable by-products of dialogue. Thus, despite his evaluation that Dabru Emet "is in many ways an admirable statement," he was not willing to be a signatory to it or to endorse it after the fact, as unpopular as that decision might have been in certain circles (p. 392).

In light of the high quality of Berger's work, it is too bad that these essays were not updated. Thus, articles written before Berger published his edition of Nizzahon Yashan refer to an older, inferior printing which is not easily available (e.g., pp. 213-215). Furthermore, despite Berger's general separation of scholarship and apologetics, sometimes his own strong religious convictions are not totally put aside, as in his defense of Nahmanides' account of the Disputation of Barcelona (pp. 199-208). Despite these caveats, this is a very valuable collection. Berger sets a very high standard for all of us who would analyze this controversial literature. At the same time, he demonstrates that objective scholars do not have to be neutral when confronted by the existential issues raised by the subject of their inquiries. The mix of historical and contemporary issues raised by this collection demonstrates that David Berger's commitment to both scholarship and theological integrity has been a hallmark of a most productive career. 